\title{
BREXIT and the J-Curve Hypothesis for the UK: A Nonlinear ARDL Approach
}

Ayşen SiVRIKAYY (https://orcid.org/0000-0003-2199-3593), Department of Economics, Hacettepe University, Turkey; e-mail: aysens@hacettepe.edu.tr

Serdar ONGAN (https://orcid.org/0000-0002-0969-4710), Department of Economics, St.Mary's College of Maryland, U.S.A.; e-mail: serdar.ongan@gmail.com

\section{BREXIT ve İngiltere için J-Eğrisi Hipotezi: NARDL Yaklaşımı}

\begin{abstract}
In this study, we investigate the validity of the J-curve hypothesis based on the bilateral trade models between the UK and its 17 main trading partner countries over the period of 1981Q1-2015Q1, by applying Nonlinear Autoregressive Distributed Lag (NARDL) cointegration approach. The results of this study suggest no evidence supporting the J-curve hypothesis between the UK and any of its 17 trading partners. We also find that depreciations and appreciations in value of the GBP have asymmetric effects on the UK's trade balances in the short-run. Therefore, the results of this study have potential to shed light on both short run and long run consequences of the recent fluctuations of the GBP with respect to the trade balances after the UK's EU membership referendum in 2016.
\end{abstract}

Keywords : J-Curve, BREXIT, Nonlinear ARDL; Asymmetry, the UK.

JEL Classification Codes : F10, F14, F31.

\section{Öz}

Bu çalışmada, İngiltere ve temel ticaret ortağı 17 ülke arasındaki ikili ticaret üzerinden J-eğrisi hipotezi araştırılmıştır. Bu amaçla, 1981Q1-2015Q1 dönemi verileri ve Doğrusal Olmayan Gecikmesi Dağıtılmış Otoregresif (NARDL) eş-bütünleşme yaklaşımı kullanılmıştır. Bu çalışmanın sonuçları, İngiltere ve 17 ticaret ortağı arasındaki ticaret için J-eğrisi hipotezinin geçerli olmadığını göstermektedir. Ayrıca, bu çalışma sonuçlarına göre, İngiliz sterlinin değerindeki azalış veya artış, İngiliz ticaret hadlerinde kısa dönemde asimetrik etkiler yaratmaktadır. Dolayısıyla bu çalışma, İngiltere'de yapılan 2016 Avrupa Birliği Üyeliği Referandumu sonrası, İngiliz sterlininin değerinde gerçekleşen dalgalanmaların kısa ve uzun dönemde İngiliz ticaret hadlerine etkisini ortaya koymaktadir.

\section{Anahtar Sözcükler $\quad$ : J-Eğrisi, BREXIT, Doğrusal Olmayan ARDL, Asimetri, İngiltere.}




\section{Introduction}

The United Kingdom (UK), one of the world's largest trading countries, is in the process of leaving the European Union (EU) (commonly known as Brexit). The impacts of this historic decision on the UK's economy started to emerge immediately after the country's EU membership referendum in June 2016. The GBP has sharply depreciated against other currencies, especially the USD and the Euro. This intense reaction of the GBP to the UK's decision has raised a question: How will the depreciations in value of the GBP affect the UK's trade balance? In this study, we address this question in terms of the J-curve hypothesis.

According to the J-curve hypothesis, introduced by Magee (1973), the depreciation of home country's real exchange rate worsens its trade balance in the short-run, but its trade balance improves gradually in the long-run as long as the Marshall-Lerner Condition (ML), developed by Marshall (1923) and Lerner (1944), is met. The pattern of the curve of this initial worsening and eventual improvement of the trade balance versus time resembles the letter "J", and is, therefore, called the "J-curve." The reason for this pattern is that a depreciation of a currency against another country's currency is expected to result in increasing the home country's export and decreasing its import.

Since Magee (1973), many scholars have tested validity of the J-curve hypothesis for several countries. Bahmani-Oskoee and Ratha (2004) and Bahmani-Oskooee and Hegerty (2010) surveyed the related literature and showed that it has produced mixed results regarding its validity. For example, Rose and Yellen (1989), Shirvani and Wilratte (1997), Bahmani-Oskooee and Brooks (1999), Wilson and Tat (2001), Wilson (2001), BahmaniOskooee and Goswami (2003), Akbostanci (2004) and Hsing et al, (2010) did not find any evidence for the validity of J-curve hypothesis. However, Krugman and Baldwin (1987), Demirden and Pastine (1995), Gupta-Kapoor and Ramakrishnan (1999), Kale (2001), Lal and Lowinger (2002), Gomes and Paz (2005), Halicioglu (2008) did find evidences of the Jcurve hypothesis.

In the related literature, a few empirical studies have also examined the J-curve hypothesis using different approaches for the UK. For instance, employing several tests involving both the seemingly unrelated and pooled cross-section time series regression techniques for 14 developed countries including the UK, Miles (1979) found that the depreciations of the GBP worsened the UK trade balances in the long-run. However, Himarrios (1985) could not reach the same result of Miles (1979) by using the similar methodology after standardizing for other variables such as government monetary and consumption policies. On the one hand, Rose and Yellen (1989) applied the methods of both Engle and Granger (1987) and Stock and Watson (1988) and could not find any evidence of J-curve hypothesis for the trade between USA and its six major trading partners including the UK in either the short run or the long-run. On the other hand, Bahmani-Oskooee and Brooks (1999), using bounds testing to cointegration and error correction modelling, found contradictory results to Rose and Yellen's (1989) in all cases except for the UK. Suspecting that the studies with contradicting results with each other might suffer from the aggregate 
bias problem, Bahmani-Oskooee and Kovyryalova (2008) tested the J-curve hypothesis between the UK and USA for 177 industries in the UK. By employing bound testing approach, they found the validity of J-curve hypothesis for 66 industries. Thus, this brief review shows that the empirical findings are mixed even for the same country. This may be resulted from the period used and/or the methodologies applied.

The abovementioned studies have all utilized empirical methodologies from Error Correction Model (ECM) (for example, Rose \& Yellen, 1989; Gupta-Kapoor \& Ramakrishnan, 1999) to Autoregressive Distributed Lag (ARDL) approach (for example, Bahmani-Oskoee \& Ardalani, 2006; Baek et al., 2009) for testing the validity of J-curve hypothesis under the linearity assumption, which suggests that a country's trade balance reacts similarly to same size increase and decrease in real exchange rates. However, it has been long recognized that the dynamics and interrelationships of many economic variables might be inherently nonlinear (Keynes, 1936; Morgan, 1993). In the context of J-curve hypothesis, an appreciation and a depreciation of a country's currency against another currency can have different effects on the country's trade balance with its corresponding trading partner. Their different effects can be stem from possible nonlinearities in real exchange rate elasticities of import and export. Therefore, incorporating symmetric responses of the trade balances to any changes in real exchange rates into a trade model can cause misleading results in testing the J-curve hypothesis. For instance, Bahmani-Oskooee and Faridditavana (2016) find evidence in favor of J-curve hypothesis only when they introduce a nonlinear adjustment process for the case of the USA. Bahmani-Oskooee et al. (2017) find that using a nonlinear adjustment process for the case of the UK leads to reveal the asymmetric effects of exchange rate changes on the country's trade balances.

In this study, we apply Shin et al.'s (2014) nonlinear ARDL cointegration approach (NARDL) to the bilateral trade models of the U.K and its main 17 trading partners, which are Germany, Italy, Japan, South Korea, the Netherlands, Spain, the USA, Austria, Canada, France, Norway, Portugal, Sweden, Australia, Denmark, Finland and Greece. This new approach enables us to examine the validity of the J-curve hypothesis by separating the effects of the depreciations and appreciations in value of the GBP against the currencies of the UK's trading partners on the corresponding trade balances. After the UK's EU membership referendum, the results of this study may shed light on both long run and short run consequences of the recent fluctuations of the GBP with respect to the trade balances.

The rest of the paper is organized as follows. Section 2 provides the empirical methodology. Section 3 explains the data set and the empirical results. Section 4 concludes.

\section{Empirical Methodology}

In order to investigate the J-curve hypothesis between the UK and its trading partner $i$, we consider the possible long-run relationship between trade balance and real exchange rate of the following form:

$$
\ln T B_{i, t}=\alpha_{0}+\alpha_{1} \ln Y_{t}^{U K}+\alpha_{2} \ln Y_{i, t}+\alpha_{3} R E X_{i, t}^{+}+\alpha_{4} R E X_{i, t}^{-}+\varepsilon_{t}
$$


Here, $\ln$ represents the natural logarithm. $T B$ is the trade balance of the UK and defined as the UK's import to trading partner $i$ divided by its export to trading partner $i$. $Y_{t}^{U K}$ and $\ln Y_{i, t}$ are the UK's and its trading partner's industrial production indexes (as proxy of income). Thus, the estimates of $\alpha_{1}$ and $\alpha_{2}$ could be positive or negative. The sign of $\alpha_{1}$ is assumed to be positive if an increase in economic growth of the UK leads to an increase in imports of the country. However, if an increase in economic growth of the country is due to an increase in the production of substitute goods, this will lead to less imports for the UK and produce a negative sign for $\alpha_{1}$. By the same token, the sign of $\alpha_{2}$ may be positive or negative. The real exchange rate $\left(R E X_{i, t}\right)$ between the GBP and the currency of the UK's trading partner $i$ is defined as $R E X_{i}=\left(N E X_{i} * C P I_{U K}\right) / C P I_{i}$ where $N E X_{i}$ is the number of units of the trade partner's currency per GBP. $C P I_{U K}$ and $C P I_{i}$ stand for the consumer prices indexes in $\mathrm{UK}$ and in its trading partner $i$, respectively.

The logarithms of the series $R E X_{i, t}$ are decomposed as $\ln R E X_{i, t}=a_{0}+a_{1} R E X_{i, t}^{+}+$ $a_{2} R E X_{i, t}^{-}$for all the trading partner country $i . R E X_{i, t}^{+}$and $R E X_{i, t}^{-}$are partial sum processes of positive and negative changes in $\ln R E X_{i, t}$ and are defined as follows:

$$
\begin{aligned}
& R E X_{i, t}^{+}=\sum_{j=1}^{t} \Delta \ln R E X_{i, t}^{+}=\sum_{j=1}^{t} \max \left(\Delta \ln R E X_{i, j}, 0\right) \\
& R E X_{i, t}^{-}=\sum_{j=1}^{t} \Delta \ln R E X_{i, t}^{-}=\sum_{j=1}^{t} \min \left(\Delta \ln R E X_{i, j}, 0\right)
\end{aligned}
$$

Because of real exchange rate definition utilized in this study, the evidence validating the J-curve hypothesis requires that the estimated $\alpha_{3}$ and $\alpha_{4}$ to be significant and that $\alpha_{3}>$ 0 , or $\alpha_{4}>0$ or both in (1). As long as a long-run relationship between trade balance and real exchange rate exists and $\alpha_{3} \neq \alpha_{4}$, significant $\alpha_{3}$ and $\alpha_{4}$ represent the asymmetric responses of trade balance to the appreciation and depreciation of the real exchange rate in the long-run.

Following Shin et al. (2014) we extend (1) to the NARDL model given in (3).

$$
\begin{gathered}
\Delta \ln T B_{i, t}=\alpha+\sum_{j=1}^{p 1} \beta_{j} \Delta \ln T B_{i, t-j}+\sum_{j=0}^{p 2} \gamma_{j} \Delta \ln Y_{t-j}^{U K}+\sum_{j=0}^{p 3} \delta_{j} \Delta \ln Y_{i, t-j} \\
+\sum_{j=0}^{p 4} \theta_{j}^{+} \Delta R E X_{i, t-j}^{+}+\sum_{j=0}^{p 5} \theta_{j}^{-} \Delta R E X_{i, t-j}^{-} \\
+\mu_{1} \ln T B_{i, t-1}+\mu_{2} \ln Y_{t-1}^{U K}+\mu_{3} \ln Y_{i, t-1}+\mu_{4} R E X_{i, t-1}^{+}+\mu_{5} R E X_{i, t-1}^{-}+\epsilon_{t}
\end{gathered}
$$



for all $j$.

NARDL model nests the linear ARDL model for the case of $\mu_{4}=\mu_{5}$ and $\theta_{j}^{+}=\theta_{j}^{-}$

Pesaran et al. (2001) proposed the Bounds Testing Procedure (BTP) which utilizes the ARDL models to test for the existence of a relationship between variables in levels. BTP is useful in empirical analyses because it is applicable irrespective of whether the regressors are purely I (0), purely I (1) or mutually cointegrated. In particular, in case some of the regressors are I (0) but the others are I (1) in a model, the BTP can be applied to investigate the existence of cointegration relationship among the regressors.

According to BTP, the null hypothesis of no cointegration is given by $\mu_{1}=\mu_{2}=$ $\mu_{3}=\mu_{4}=\mu_{5}=0$ in (3), which can be tested using Wald or $F$-statistics. Since the distribution of the test statistics is nonstandard, Pesaran et al. (2001) tabulated two sets of critical values as the lower bounds and upper bounds for given significance levels. If the computed statistics falls below the lower bound, the conclusive decision can be made in favor of no cointegration. If it exceeds the upper bound, it indicates cointegration. If, however the statistics is within these bounds, inference is inconclusive.

After the NARDL model is estimated, its estimates can be used to investigate whether the short-run response of trade balance to real exchange rate depreciation and appreciation is asymmetric. Shin et al. (2014) proposed that the short run asymmetry could be tested by using Wald test for the null hypothesis of $\sum_{j=0}^{p 4} \theta_{j}^{+}=\sum_{j=0}^{p 5} \theta_{j}^{-}$in (3).

\section{Data Set and Empirical Results}

The data used in this paper are quarterly figures of 17 countries covering the period of 1981Q1-2015Q1 ${ }^{1}$. The series of trade balance (TB) are obtained from the IMF's Direction of Trade Statistics. The series for the countries' industrial production indexes are obtained from the database of the Federal Reserve Bank of St. Louis $(2010=100)$. To calculate the real exchange rate $(R E X)$ series between the GBP and the currencies of the UK's trade partners, the series for $N E X, C P I_{U K}$ and $C P I_{T P}$ are obtained from the database of the Federal Reserve Bank of St. Louis (FED). All data are seasonally adjusted.

In this study, we pursue the following empirical process for each case of the UK and its trade partner in pairs. First, we examine the order of the integration in the time series used in (1). Even though we are able to apply the NARDL model given in (3) irrespective of whether they are either $I(0)$ or $I(1)$, we have to make sure that their orders of integration are not 2 or higher. In order to identify the orders of the integration of time series, we use 
the Augmented Dickey Fuller Unit Root Test (ADF), whose results are reported in the Table 1. Table 1 shows that all series used in (1) are either $I(0)$ or $I(1)$.

Table: 1

ADF Unit Root Tests Results

\begin{tabular}{|c|c|c|c|c|c|c|}
\hline Country & $\ln T B_{t}$ & $\Delta \ln T B_{t}$ & $\ln Y_{t}$ & $\Delta \ln Y_{t}$ & $R E X_{t}^{+}$ & $R E X_{t}^{-}$ \\
\hline Australia & $-1,896$ & $-11,389 * * *$ & $-0,457$ & $-10,921 * * *$ & $-9,699 * * *$ & $-10,360 * * *$ \\
\hline Austria & $-2,051$ & $-13,062 * * *$ & $-0,777$ & $-5,844 * * *$ & $-8,830 * * *$ & $-8,474 * * *$ \\
\hline Canada & $-1,538$ & $-16,335 * * *$ & $-1,361$ & $-5,667 * * *$ & $-7,646 * * *$ & $-8,083 * * *$ \\
\hline Denmark & $-3,172 * *$ & $-14,627 * * *$ & $-2,635$ & $-6,282 * * *$ & $-9,283 * * *$ & $-8,283^{* * * *}$ \\
\hline Finland & $-2,105$ & $-9,785^{* * *} *$ & $-1,524$ & $-9,358 * * *$ & $-8,877 * * *$ & $-9,141 * * *$ \\
\hline France & $-4,137 * * *$ & $-13,380 * * *$ & $-1,986$ & $-7,549 * * *$ & $-8,849 * * *$ & $-9,385 * * *$ \\
\hline Germany & $-2,745^{*}$ & $-12,823 * * *$ & $-1,028$ & $-7,975 * * *$ & $-8,505 * * *$ & $-8,537 * * *$ \\
\hline Greece & $-1,866$ & $-17,162 * * *$ & $-1,277$ & $-13,935^{* * * *}$ & $-8,046 * * *$ & $-9,014 * * *$ \\
\hline Italy & $-1,818$ & $-14,475 * * *$ & $-1,717$ & $-6,958^{* * *}$ & $-8,927 * * *$ & $-8,678 * * *$ \\
\hline Japan & $-0,838$ & $-16,412 * * *$ & $-2,945^{* *}$ & $-7,809 * * *$ & $-7,883 * * *$ & $-9,251 * * *$ \\
\hline Korea & $-2,585^{*}$ & $-16,640 * * *$ & $-2,898 * *$ & $-6,057 * * *$ & $-7,701 * * *$ & $-9,675^{* * *}$ \\
\hline Netherlands & $-2,322$ & $-12,941 * * *$ & $-1,297$ & $-14,213 * * *$ & $-8,278 * * *$ & $-8,730 * * *$ \\
\hline Norway & $-1,884$ & $-15,399 * * *$ & $-2,977 * *$ & $-16,208 * * *$ & $-8,842 * * *$ & $-10,260 * * *$ \\
\hline Portugal & $-2,183$ & $-17,733 * * *$ & $-3,065^{* *}$ & $-10,978 * * *$ & $-8,768 * * *$ & $-9,260 * * *$ \\
\hline Spain & $-1,416$ & $-13,374 * * *$ & $-2,072$ & $-4,587 * * *$ & $-7,917 * * *$ & $-9,104 * * *$ \\
\hline Sweden & $-2,946 * *$ & $-12,474 * * *$ & $-1,741$ & $-8,761 * * *$ & $-9,408 * * *$ & $-9,299 * * *$ \\
\hline USA & $-3,204 * *$ & $-14,726 * * *$ & $-0,935$ & $-5,336^{* * *}$ & $-7,932 * * *$ & $-8,454 * * *$ \\
\hline UK & & & $-2,704^{*}$ & $-8,052 * * *$ & & \\
\hline
\end{tabular}

Note: ADF regressions include an intercept. *, ** and $* * *$ denote rejection of the null hypothesis of unit root for the ADF tests at $10 \%, 5 \%$ and $1 \%$ significance levels, respectively.

After confirming that the times series under investigation are $I(0)$ or $I(1)$, we estimate each NARDL model for the UK and its trading partner $i$ for $i=1,2 \ldots 17$ as specified in (1). The optimal lags in each NARDL model are selected using Akaike Information Criterion (AIC). We impose a maximum of eight lags on each first differenced variable. The estimation results of each optimal NARDL model are reported in Table 2.

Table: 2

NARDL Models' Statistics for Bilateral Trade Models between the UK and Its Trade Partners ${ }^{(1)}$

\begin{tabular}{|c|c|c|c|c|c|c|c|c|}
\hline Trading Partner & $\begin{array}{l}\text { NARDL Model } \\
(p 1, p 2, p 3, p 4, p 5)\end{array}$ & $F-s t a t$ & $W_{\text {short }}$ & RESET & CUSM & $C U S M^{2}$ & LM Test & Adj. $R^{2}$ \\
\hline Australia & $(4,6,0,2,0)$ & 2,281 & $4,288^{* * *}$ & 7,302 & $\mathrm{~S}$ & $\mathrm{~S}$ & 0,427 & 0,459 \\
\hline Austria & $(6,1,0,0,3)$ & 1,250 & 1,315 & 2,519 & $\mathrm{~S}$ & $\mathrm{~S}$ & 0,132 & 0,082 \\
\hline Canada & $(1,0,4,27)$ & $4,243^{* * *}$ & $10,951 * * *$ & 4,740 & $\mathrm{~S}$ & $\mathrm{~S}$ & 0,735 & 0,323 \\
\hline Denmark & $(8,0,0,1,0)$ & 0,837 & 0,634 & 0,481 & $\mathrm{~S}$ & $\mathrm{~S}$ & 1,532 & 0,217 \\
\hline Finland & $(8,2,7,1,1)$ & 0,919 & $5,725^{* *} *$ & 0,075 & $\mathrm{~S}$ & $\mathrm{~S}$ & 0,001 & 0,391 \\
\hline France & $(1,0,0,0,0)$ & $3,778^{*}$ & 0,477 & 16,468 & $\mathrm{~S}$ & $\mathrm{~S}$ & 0,442 & 0,092 \\
\hline Germany & $(4,0,1,0,0)$ & 1,596 & 1,446 & 0,201 & $\mathrm{~S}$ & $\mathrm{~S}$ & 0,159 & 0,112 \\
\hline Greece & $(1,0,2,0,3)$ & $3,808^{*}$ & $4,157 * *$ & 0,008 & $\mathrm{~S}$ & $\mathrm{~S}$ & 0,261 & 0,204 \\
\hline Italy & $(4,0,8,1,0)$ & 0,670 & 0,083 & 0,000 & $\mathrm{~S}$ & $\mathrm{~S}$ & 0,357 & 0,141 \\
\hline Japan & $(8,0,1,7,0)$ & 0,679 & $10,782 * * *$ & 0,053 & $\mathrm{~S}$ & $\mathrm{~S}$ & 0,919 & 0,266 \\
\hline Korea & $(1,0,0,0,0)$ & $3,854 *$ & $4,779^{* *}$ & 1,591 & $\mathrm{~S}$ & $\mathrm{~S}$ & 4,093 & 0,238 \\
\hline Netherlands & $(1,6,5,6,0)$ & 1,453 & 0,055 & 1,411 & $\mathrm{~S}$ & $\mathrm{~S}$ & 0,002 & 0,300 \\
\hline Norway & $(1,0,4,0,0)$ & $4,230 * *$ & 0,348 & 1,070 & $\mathrm{~S}$ & $\mathrm{~S}$ & 1,649 & 0,218 \\
\hline Portugal & $(1,1,0,0,2)$ & 1,885 & 0,610 & 0,254 & $\mathrm{~S}$ & $\mathrm{~S}$ & 0,695 & 0,208 \\
\hline Spain & $(8,0,2,0,6)$ & 0,487 & $12,753^{* * * *}$ & 0,355 & $\mathrm{~S}$ & $\mathrm{~S}$ & 0,487 & 0,197 \\
\hline Sweden & $(4,5,4,7,2)$ & $3,697^{*}$ & $11,205^{* * *} *$ & 0,895 & $\mathrm{~S}$ & $\mathrm{~S}$ & 0,318 & 0,239 \\
\hline USA & $(1,2,3,0,0)$ & 3,395 & 1,562 & 2,057 & $\mathrm{~S}$ & $\mathrm{~S}$ & 1,288 & 0,186 \\
\hline
\end{tabular}

Notes: ${ }^{(I)}$ The parameter estimates of the NARDL models are available upon request.

*, ** and *** denote rejection of the null hypothesis of no cointegration for BTP and rejection of the null hypothesis of short run asymmetry at $10 \%$ and $5 \%$ significance levels, respectively. $p_{i}$ for $i=1 . .5$ represents the optimal lags in the estimated NARDL models given in Eq. (3). 
After estimating (3) for each bilateral trade model, we use the estimated coefficients to investigate the long-run relationship between real exchange rates and trade balances. To this end, the BTP is applied to each estimated NARDL model. According to BTP, the null hypothesis of no cointegration, established as $\mu_{1}=\mu_{2}=\mu_{3}=\mu_{4}=\mu_{5}=0$, in the (3), is tested by the familiar $F$ test, whose statistics are given in Table 2 as $F-$ stat. The critical values for $F$ - stat, as tabulated by Pesaran et al. (2001), within a model of four exogenous variables with unrestricted intercept and no trend are 3.52 and 4.01 for upper bound and 2.45 and 2.86 for lower bound at the $10 \%$ and $5 \%$ significance level, respectively. The test result indicate cointegration only when the $F$ - stat exceeds the upper bound, specifically 3.52 at $10 \%$ significance level and 4.01 at $5 \%$ significance level. As can be seen from Table 2, only for the models involving Canada, France, Greece, Korea, Norway and Sweden are the F stats greater than the upper bound. Consequently, we are able to investigate the validity of the J-curve hypothesis for the UK with only these six countries.

We also utilize the estimates of NARDL models given in Table 2 to investigate whether the short-run reaction of trade balance is asymmetric with respect to real exchange rate depreciation and appreciation. The rejection of the null hypothesis of $\sum_{j=0}^{p 4} \theta_{j}^{+}=$ $\sum_{j=0}^{p 5} \theta_{j}^{-}$in (3) suggests asymmetry for $\mathrm{i}=0 \ldots p 4$ and for $j=0 \ldots p 5$. To test the null hypothesis, we apply the Wald tests to the estimated NARDL models. The Wald statistics are reported in Table 2 as $W_{\text {short }}$. As can be seen from Table (2), $W_{\text {short }}$ is significant for Australia, Canada, Finland, Greece, Japan, Korea, Spain and Sweden, which suggests that there is short-run asymmetry in the bilateral trade between the UK and these countries. Once we establish the cointegration relationship for the bilateral trade between the UK and Canada, France, Greece, Korea, Norway and Sweden, we run the regression given in (1) for the bilateral long-run trade models for the UK and these trading partners. Table 3 presents the coefficient estimates of those models.

Table: 3

The Coefficient Estimates: The Long-Run Trade Models

\begin{tabular}{|c|c|c|c|c|c|c|c|}
\hline & & Canada & France & Greece & Korea & Norway & Sweden \\
\hline Constant & & $\begin{array}{l}8,324 \\
(7,460)\end{array}$ & $\begin{array}{l}-0,415 \\
(-0,648)\end{array}$ & $\begin{array}{l}9,497 \\
(8,686)\end{array}$ & $\begin{array}{l}-12,239 \\
(-8,560)\end{array}$ & $\begin{array}{l}13,472 \\
(3,611)\end{array}$ & $\begin{array}{l}-1,913 \\
(-2,258)\end{array}$ \\
\hline & $\ln Y_{t}^{U K}$ & $\begin{array}{l}-3,755 \\
(-10,731)\end{array}$ & $\begin{array}{l}0,916 \\
(3,080)\end{array}$ & $\begin{array}{l}-2,123 \\
(-6,224)\end{array}$ & $\begin{array}{l}3,157 \\
(9,462)\end{array}$ & $\begin{array}{l}-4,784 \\
(-3,673)\end{array}$ & $\begin{array}{l}0,372 \\
(1,452)\end{array}$ \\
\hline & $\ln Y_{i, t}$ & $\begin{array}{l}2,074 \\
(12,229)\end{array}$ & $\begin{array}{l}-0,814 \\
(-2,323)\end{array}$ & $\begin{array}{l}-0,087 \\
(-0,259)\end{array}$ & $\begin{array}{l}-0,506 \\
(-11,790)\end{array}$ & $\begin{array}{l}2,156 \\
(3,968)\end{array}$ & $\begin{array}{l}0,086 \\
(0,790)\end{array}$ \\
\hline & $R E X_{i, t}^{+}$ & $\begin{array}{l}-1,751 \\
(-3,398)\end{array}$ & $\begin{array}{l}0,645 \\
(0,867)\end{array}$ & $\begin{array}{l}1,124 \\
(0,824)\end{array}$ & $\begin{array}{l}0,612 \\
(0,922)\end{array}$ & $\begin{array}{l}-0,328 \\
(-0,129)\end{array}$ & $\begin{array}{l}-0,313 \\
(-0,412)\end{array}$ \\
\hline & $R E X_{i, t}^{-}$ & $\begin{array}{l}0,037 \\
(0,064)\end{array}$ & $\begin{array}{l}-1,170 \\
(-1,999)\end{array}$ & $\begin{array}{l}0,299 \\
(0,252)\end{array}$ & $\begin{array}{l}-2,941 \\
(-3,539)\end{array}$ & $\begin{array}{l}-0,583 \\
(-0,251)\end{array}$ & $\begin{array}{l}0,205 \\
(0,199)\end{array}$ \\
\hline \multicolumn{8}{|c|}{ Diagnostic Statistics: } \\
\hline RESET & & 13,004 & 3,823 & 19,938 & 10,220 & 3,962 & 79,136 \\
\hline CUSM & & US & $\mathrm{s}$ & US & US & US & US \\
\hline CUSM $^{2}$ & & US & US & US & US & US & US \\
\hline LM Test & & $101,415 * * *$ & $63,373^{* * * *}$ & $147,600^{* * *}$ & $83,190 * * *$ & $336,263 * * * *$ & 235,576 *** \\
\hline Adj. $R^{2}$ & & 0,554 & 0,068 & 0,412 & 0,562 & 0,085 & 0,066 \\
\hline
\end{tabular}

The J-curve hypothesis is accepted to be valid when at least one of the estimates of the coefficients associated with real exchange rates is significantly positive. In particular, 
significantly positive $\alpha_{3}$ and/or $\alpha_{4}$ provide evidence of the validity of the J-curve hypothesis for the case of the UK and its trading partner under investigation. As can be seen from Table 3 , none of the coefficient estimates of $R E X_{i, t}^{+}$and $R E X_{i, t}^{-}$are significantly positive. To be more specific, the coefficient estimates of UK's $R E X_{i, t}^{+}$and $R E X_{i, t}^{-}$are not significant for the bilateral trade models with Greece, Norway and Sweden. Additionally, for the cases that are significant, such as the coefficient estimate of real exchange rate appreciation, $R E X_{i, t}^{+}$, for Canada and the real exchange rate depreciation, $R E X_{i, t}^{-}$, for France and Korea, the signs are not positive.

Therefore, this study provides no evidence of the J-curve hypothesis for the UK with not only Canada, France, Greece, Korea, Norway and Sweden but also the other 11 countries which we cannot find any evidence for long-run relationships. Moreover, the estimated coefficients of the UK's and its trading partners' industrial production indexes are significantly positive and significantly negative (as expected), respectively only for the longrun trade models between the UK and France the UK and Korea.

We also report the results of several diagnostic tests for the estimated NARDL models in Table 2 and the estimated long-run trade models in Table 3 . In order to test the misspecification of the optimum models, we apply the Ramsey's RESET statistics which are provided by RESET in Table 2. A Ramsey's RESET statistic is distributed as $\chi^{2}$ with one degree of freedom with its critical value of 3.84. Our calculated statistics are insignificant in most short run-models, supporting that the optimum models are correctly specified, the exceptions of which are the cases of Australia, Canada and France. $S$ and $U S$ stand for the stability and instability of the coefficients for the estimated models respectively, according to the results of CUSM and $C U S M^{2}$ tests. As can be seen in the Table 2, all estimated coefficients in NARDL models are stable while those in the long-run trade models are unstable. Given as $L M$, a Breusch-Godfrey Serial Correlation LM statistic has a $\chi^{2}$ distribution with four degrees of freedom with critical value of 9.49. Our calculated LM statistics are insignificant for almost all models, implying that the estimated residuals are not auto-correlated. Adj. $R^{2}$ statistics belonging to the estimated models are also shown to report the goodness of fit.

\section{Conclusion}

In this paper, we investigate the validity of the J-curve hypothesis between the UK and its 17 main trading partners, which are Germany, Italy, Japan, South Korea, the Netherlands, Spain, the USA, Austria, Canada, France, Norway, Portugal, Sweden, Australia, Denmark, Finland and Greece, over the period of 1981Q1-2015Q1. To this end, we apply the NARDL cointegration approach. This new approach enables us to analyze the separate effects of the depreciations and appreciations of the GBP on the UK's trade balances in the process of leaving the EU and in the wake of recent depreciation in value of the GBP.

The bound testing results of this study reveal that the UK's real exchange rates and the trade balances between the UK and only six trading partners such as Canada, France, 
Greece, Korea, Norway and Sweden move together in the long run. But, the estimates of the corresponding long run trade models indicate no evidence of the J-curve hypothesis. This result is consistent with the Miles' (1976), which supports the global monetarist position. Specifically, while depreciations of the GBP against the Euro (France) and Korean Won do not improve the UK's trade balances with France and Korea, the appreciation of the GBP against the Canadian Dollar does not worsen the UK's trade balances with Canada in the long-run. Overall, in this study we find that the depreciations and appreciations of the GBP do not have long-run effects on the trade balances of the UK not only with EU member countries but also the countries outside the EU in the long run. However, the results of this study suggest that in the short run, depreciations and appreciations of the GBP have asymmetric effects on the trade balance of the country with Australia, Canada, Finland, Greece, Japan, Korea, Spain and Sweden.

Recent literature has investigated the potential effects of the UK's leaving the EU on the country's economy. Among them, two scenarios such as optimistic and pessimistic are expected to take place after the process of Brexit is completed. The optimistic scenario assumes that in a post-Brexit situation, the UK will sign a new trade agreement based on notariffs barriers between the UK and the EU, similar to the EU's agreements with Norway and Switzerland. The pessimistic scenario is based on a negotiation resulting in tariff barriers between the UK and the EU. On the one hand, Springford and Tilford (2014) believe that expecting an agreement with the EU in terms of the optimistic approach is not realistic for the UK because the size of the UK's economy is larger than the sizes of the economies of Norway and Switzerland. On the other hand, Dhingra et al. (2016) examine the effects of the two scenarios on the UK's trade. In particular, they find that Brexit will negatively affect the UK's trade at a rate of $-2.92 \%$ for the pessimistic scenario and $-1.37 \%$ for optimistic scenario. Irrespective of the fact that whether optimistic or pessimistic scenarios will be realized, our study provides an insightful projection of the potential effects of Brexit on the UK's trade balances according to the country's trading partner countries, which might help the British policy makers take necessary actions to deal with the fluctuations of the GBP.

\section{References}

Akbostanci, E. (2004), "Dynamics of the Trade Balance: The Turkish J-Curve”, Emerging Markets Finance and Trade, 40, 57-73.

Baek, J.W. \& W. Koo \& K. Mulik (2009), "Exchange Rate Dynamics and the Bilateral Trade Balance: The Case of U.S. Agriculture", Agricultural and Resource Economics Review, $38(2), 213-228$.

Bahmani-Oskooee, M. \& S.H. Ghodsi \& F. Halicioglu (2017), "UK trade balance with its trading partners: An asymmetry analysis", Economic Analysis and Policy, 56, 188-199.

Bahmani-Oskooee, M. \& A. Ratha (2004), “The J-Curve: a literature review”, Applied Economics, 36, 1377-1398.

Bahmani-Oskooee, M. \& G.G. Goswami (2003), “Exchange Rate Sensitivity of Japan's Bilateral Trade Flows", Japan and the World Economy, 16, 1-15.

Bahmani-Oskooee, M, \& H. Fariditavana (2016), "Nonlinear ARDL Approach and the J Curve Phenomenon", Open Economies Review, 27, 51-70. 
Bahmani-Oskooee, M. \& M. Kovyryalova (2008), “The J-Curve: Evidence from Industry Trade Data between US and UK”, Economic Issues, 13, 25-44.

Bahmani-Oskooee, M. \& S.W. Hegerty (2010), "The J- and S-curves: A Survey of the Recent Literature", Journal of Economic Studies, 37(6), 580-596.

Bahmani-Oskooee, M. \& T.J. Brooks (1999), "Bilateral J-Curve between US and her Trading Partners", Weltwirtschaftliches Archiv, 135, 156-165.

Bahmani-Oskooee, M. \& Z. Ardalani (2006), "Exchange Rate Sensitivity of U.S. Trade Flows: Evidence from Industry Data", Southern Economic Journal, 72(3), 542-559.

Demirden, T. \& I. Pastine (1995), "Flexible Exchange Rates and the J-curve: An Alternative Approach", Economics Letters, 48, 373-377.

Dhingra, S. \& G. Ottaviano \& T. Sampson \& J. Van Reenen (2016), The consequences of Brexit for UK trade and living standards, Centre for Economic Performance (CEP), London School of Economics and Political Science (LSE).

Engle. R.F. \& C.W.J. Granger (1987), “Co-integration and error correction: Representation, estimation and testing”, Econometrica, 55, 1251-1276.

Gomes, F.A.R. \& L.S. Paz (2005), "Can real exchange rate devaluation improve the trade balance? The 1990-1998 Brazilian case", Applied Economics Letters, 12, 525-528.

Gupta-Kapoor, A. \& U. Ramkrishnan (1999), "Is There a J-Curve? A New Estimation for Japan", International Economic Journal, 13, 71-79.

Halicioglu, F. (2008), “The J-Curve Dynamics of Turkey: An Application of ARDL Model”, Applied Economics, 40, 2423-2439.

Himarrios, D. (1985), "The Effects of Devaluation on the Trade Balance: A Critical View and Reexamination of Miles's 'New Results' “, Journal of International Money and Finance, 4, 553-563.

Hsing, Y. \& B.S. Sergi (2010), "Test of the bilateral trade J-curve between the USA and Australia, Canada, New Zealand and the UK", International Journal of Trade and Global Markets, 3(2), 189-198.

Kale, P. (2001), "Turkey's trade balance in the short and the long-run: error correction modelling and cointegration", The International Trade Journal, XV, 27-56.

Keynes, J.M. (1936), The General Theory of Employment, Interest, and Money, MacMillan: London.

Krugman, P.R. \& R.E. Baldwin (1987), “The Persistence of US Trade Deficit”, Brookings Papers on Economic Activity, 1, 1-43.

Lal A.K. \& T.C. Lowinger (2002), “The J-curve: Evidence from East Asia”, Journal of Economic Integration, 17, 397-415.

Lerner, A. (1944), The Economics of Control, Macmillan: London.

Magee, S.P. (1973), “Currency contracts, pass through and devaluation”, Brooking Papers on Economic Activity, 1, 303-25.

Marshall, A. (1923), Money, Credit and Commerce, Macmillan: London.

Miles, M.A. (1979), "The Effects of Devaluation on the Trade Balance and Balance of Payments: Some New Results", Journal of Political Economy, 87, 600-619.

Morgan, D.P. (1993), “Asymmetric effects of monetary policy”, Federal Reserve Bank of Kansas City Economic Review, 78, 21-33. 
Pesaran, M.H. \& Y. Shin \& R.J. Smith (2001), "Bounds Testing Approaches to the Analysis of Level Relationships", Journal of Applied Econometrics, 16, 289-326.

Rose, A.K. \& J.I. Yellen (1989), "Is There a J-Curve?", Journal of Monetary Economics, 24, 53-68.

Shin, Y. \& B. Yu \& M. Greenwood-Nimmo (2014), "Modelling Asymmetric Cointegration and Dynamic Multipliers in a Nonlinear ARDL Framework", in: R. Sickels \& W. Horrace (eds.), Festschrift in Honor of Peter Schmidt: Econometric Methods and Applications, Springer, 281-314.

Shirvani, H. \& B. Wilbratte (1997), "The Relation between the Real Exchange Rate and the Trade Balance: An Empirical Reassessment”, International Economic Journal, 11, 39-50.

Springford, J. \& S. Tilford (2014), “The Great British trade-off”, Discussion Paper, Centre for European Reform.

Stock, J.H. \& M.W. Watson (1988), “Testing for common trends”, Journal of the American Statistical Association, 83(404), 1097-1107.

Wilson, P. (2001), "Exchange rates and the trade balance for dynamic Asian economies: Does the Jcurve exist for Singapore, Malaysia and Korea", Open Economic Review, 12, 389-413.

Wilson, P. \& K.C. Tat (2001), "Exchange Rates and the Trade Balance: The Case of Singapore 1970 to 1996", Journal of Asian Economics, 12, 47-63. 